\title{
Effect of Nitrogen Rates, Harvest Interval and Cutting Heights on Yield and Composition of Star Grass in Puerto Rico ${ }^{1,2}$
}

\author{
Rubén Caro-Costas, Fernando Abruña, and Jacinto Figarella ${ }^{3}$
}

\section{INTRODUCTION}

Considerable information exists concerning the response to nitrogen fertilization of grasses such as Pangola grass (Digitaria decumbens) Guinea grass (Panicum maximum Jacq.) and Napier grass (Pennisetum purpureum Schum.) as affected by cutting height and harvest interval $(2,3,8,9,10$, 11,12).

This report presents data from experiments designed to indicate response of a local cultivar of Star grass (Cynodon dactylon) to nitrogen fertilization and interactions with height of cutting and harvest intervals.

\section{MATERIALS AND METHODS}

The experiments were conducted over 2 consecutive years at Orocovis where the mean annual temperature is about $70^{\circ} \mathrm{F}$. Rainfall during the first year (April 1967-April 1968) totalled 64 inches and 95 inches during the second (April 1968-April 1969). The long-time average is 68 inches.

The soil is Humatas clay, a deep, red, well-drained Typic Tropohumults with a 20-percent slope. The surface 0 - to 6 -inch layer initially averaged 4.7 percent organic matter, 0.31 percent nitrogen and a cation exchange capacity ${ }^{4}$ of 15 meq. per $100 \mathrm{~g}$.

Four harvest intervals $(30,45,60$ and 90 days), two cutting heights (2 inches and 6 inches from the ground) and 5 nitrogen levels $(0,200,400$, 600 and 800 pounds per acre yearly) were investigated. The combination of these variables resulted in $\mathbf{4 0}$ treatments, each replicated 3 times, totalling 120 plots.

A split-split plot design was employed, with the two cutting heights as the main plots. The first split corresponded to the harvest interval, and the nitrogen levels to the sub-subplots. Individual plots were 10 feet by 15 feet,

1 Manuscript submitted to Editorial Board March 2, 1971.

2 This report covers research conducted cooperatively between the Soil and Water Conservation Research Division, Agricultural Research Service, USDA, and the Agricultural Experiment Station, Mayaguiez Campus, University of Puerto Rico, Río Piedras, P.R.

${ }^{3}$ Agronomist (cooperative between agencies mentioned above), Soil Scientist and Chemist, SWCRD, ARS, USDA, respectively.

- Determined with normal, neutral, ammonium acetate. 
equivalent to $1 / 290$ of an acre, and each was surrounded by ditches to prevent fertilizer from washing into adjoining plots.

The soil was limed to a $\mathrm{pH}$ of about 6.0 at the start of the experiments. All plots received 72 pounds of $P$ per acre yearly applied as triple superphosphate and 600 pounds of $\mathrm{K}$ as potassium sulfate. Ammonium sulfate was the source of nitrogen. Annual fertilizer rates were divided by the number of harvests per year for each treatment and the particular fractions were applied at each harvest.

The grass in all plots was cut and weighed at the designated interval and height. Green forage samples from each plot were dried at $70^{\circ} \mathrm{C}$. and analyzed for both dry matter and protein content. Samples the second year were composited by plots and analyzed for phosphorus, potassium, calcium and magnesium. Selected samples from the 600-pound nitrogen rate at the two cutting heights and the four harvest intervals were analyzed in vitro for digestibility according to the Van Soest method (12), and for micronutrients at the USDA Plant, Soil and Nutrition Laboratory. ${ }^{5}$ During the first year, composite samples by plots in the 600-pound nitrogen rate were analyzed for lignin content at various cutting heights and intervals. The proportion and composition of leaves and stems were determined in selected samples from the 200- and 600-pound nitrogen rates at the 30-, 45- and 60-day cutting intervals.

\section{RESULTS}

\section{EFFECT OF NITROGEN FERTILIZATION}

Dry matter yields of Star grass increased with nitrogen fertilization at the two cutting heights tested, as shown in table 1, and figures 1 and 2 . Response at the various harvest intervals, however, was dependent on cutting height.

Low cut Star grass responded sharply up to 400 pounds of nitrogen when harvested every 30 days. Response was small but persistent from there on up to 800 pounds of nitrogen. When the grass was harvested at 45 days, a sharp response occurred up to 600 pounds of nitrogen and at a slower rate up to 800 pounds. At the 60 -day interval there was a sharp response only to 400 pounds of nitrogen. A persistent response up to 800 pounds of nitrogen resulted when the grass was cut every 90 days.

High cut Star grass responded sharply to 600 pounds of nitrogen when harvested at 30 days, and at a slower rate thereafter. There was a sharp response to the 400-pound level when the grass was cut at 45, 60 or 90 days.

s Appreciation is expressed to Dr. Van Soest of Cornell University and to Dr. Grunes of the Plant, Soil and Nutrition Laboratory, SWCRD, ARS, USDA, Ithaca, N.Y., for analyses of submitted samples. 
Response was meager from there on, however, except at the 45-day interval which showed a persistent response up to the 800-pound rate.

Dry matter yields were higher during the first year at all nitrogen rates and harvest intervals. The excess of rainfall during the short and cooler

TABLE 1.-Effect of cutting height, harvest inlerval, nitrogen rates and their interaction on dry maller and crude prolein yiclds and content of Slar grass (figures represent average for 2 years)

\begin{tabular}{|c|c|c|c|c|c|c|c|c|c|c|c|}
\hline \multirow{2}{*}{$\begin{array}{c}\text { Har- } \\
\text { vest } \\
\text { inter- } \\
\text { val }\end{array}$} & \multirow[b]{2}{*}{$\begin{array}{c}\text { Nitro- } \\
\text { gen } \\
\text { rates }\end{array}$} & \multicolumn{5}{|c|}{$\begin{array}{l}\text { High cut (simulated grazing) } \\
\text { ( } 6 \text { inches from the ground) }\end{array}$} & \multicolumn{5}{|c|}{ Low cut ( 2 inches from the ground) } \\
\hline & & $\underset{\substack{\text { Dry } \\
\text { matter } \\
\text { yield }}}{ }$ & $\begin{array}{c}\text { Dry } \\
\text { matter } \\
\text { con- } \\
\text { tent }\end{array}$ & $\begin{array}{l}\text { Crude } \\
\text { pro- } \\
\text { tein } \\
\text { con- } \\
\text { tent }\end{array}$ & $\begin{array}{c}\text { Crude } \\
\text { pro- } \\
\text { teip } \\
\text { yield }\end{array}$ & $\begin{array}{c}\text { Nitro- } \\
\text { gen re- } \\
\text { covered } \\
\text { in } \\
\text { forage }\end{array}$ & $\begin{array}{c}\text { Dry } \\
\text { matter } \\
\text { yield }\end{array}$ & $\begin{array}{c}\text { Dry } \\
\text { matter } \\
\text { con- } \\
\text { tent }\end{array}$ & $\begin{array}{l}\text { Crude } \\
\text { pro- } \\
\text { tein } \\
\text { con- } \\
\text { tent }\end{array}$ & $\begin{array}{l}\text { Crude } \\
\text { pro- } \\
\text { tein } \\
\text { yield }\end{array}$ & $\begin{array}{c}\text { Nitro- } \\
\text { gen re- } \\
\text { covered } \\
\text { in } \\
\text { forage }\end{array}$ \\
\hline Days & $\begin{array}{c}\text { Pounds/ } \\
\text { acrel } \\
\text { year }\end{array}$ & $\begin{array}{l}\text { Pounds/ } \\
\text { ocred } \\
\text { year }\end{array}$ & $\begin{array}{l}\text { Per- } \\
\text { eent }\end{array}$ & $\begin{array}{l}\text { Per- } \\
\text { cent }\end{array}$ & $\mid \begin{array}{c}\text { Pounds } \\
\text { acrel } \\
\text { year }\end{array}$ & $\begin{array}{l}\text { Per- } \\
\text { cent }\end{array}$ & $\begin{array}{c}\text { Pounds/ } \\
\text { acrel } \\
\text { year }\end{array}$ & $\begin{array}{l}\text { Per- } \\
\text { cent }\end{array}$ & $\begin{array}{l}\text { Per- } \\
\text { cent }\end{array}$ & $\begin{array}{c}\text { Pounds } \\
\text { acre/ } \\
\text { year }\end{array}$ & $\begin{array}{l}\text { Per- } \\
\text { cent }\end{array}$ \\
\hline \multirow[t]{5}{*}{30} & 0 & 9,073 & 23.2 & 14.0 & 1,226 & - & 10,860 & 24.4 & 12.8 & 1,390 & - \\
\hline & 200 & 10,700 & 24.4 & 13.1 & 1,402 & 11.0 & 14,271 & 24.0 & 13.4 & 1,908 & 41.5 \\
\hline & 400 & 14,927 & 22.5 & 14.4 & 2,152 & 35.5 & 16,980 & 21.8 & 14.6 & 2,477 & 43.5 \\
\hline & 600 & 18,086 & 21.9 & 15.8 & 2,863 & 42.7 & 18,401 & 20.8 & 17.0 & 3,132 & 46.5 \\
\hline & 800 & 19,333 & 21.2 & 17.0 & 3,303 & 40.5 & 19,387 & 20.3 & 17.8 & 3,449 & 41.2 \\
\hline \multirow[t]{5}{*}{45} & 0 & 9,268 & 25.6 & 11.1 & 1,032 & - & 13,344 & 24.8 & 10.7 & 1,434 & - \\
\hline & 200 & 14,906 & 24.8 & 11.0 & 1,635 & 48.2 & 18,000 & 24.8 & 9.8 & 1,767 & 26.7 \\
\hline & 400 & 19,598 & 24.3 & 11.4 & 2,244 & 48.5 & 21,464 & 24.1 & 11.1 & 2,380 & 37.9 \\
\hline & 600 & 21,444 & 24.1 & 13.0 & 2,782 & 46.7 & 25,495 & 22.7 & 13.0 & 3,311 & 50.0 \\
\hline & 800 & 22,696 & 23.3 & 13.9 & 3,156 & 42.5 & 26,812 & 22.6 & 14.0 & 3,741 & 46.1 \\
\hline \multirow[t]{5}{*}{60} & 0 & 12,117 & 29.6 & 9.0 & 1,091 & - & 19,080 & 31.0 & 8.6 & 1,630 & - \\
\hline & 200 & 16,864 & 28.6 & 9.4 & 1,580 & 39.1 & 22,086 & 29.8 & 8.6 & 1,877 & 19.0 \\
\hline & 400 & 22,788 & 28.6 & 9.9 & 2,257 & 46.6 & 29,945 & 28.2 & 9.7 & 2,899 & 50.4 \\
\hline & 600 & 24,364 & 26.6 & 11.3 & 2,744 & 44.1 & 29,624 & 28.0 & 10.6 & 3,151 & 40.3 \\
\hline & 800 & 24,033 & 26.7 & 12.4 & 2,970 & 37.2 & 29,508 & 27.9 & 11.9 & 3,514 & 37.5 \\
\hline \multirow[t]{5}{*}{90} & 0 & 15,589 & 31.0 & 7.3 & 1,141 & - & 20,918 & 31.2 & 6.8 & 1,422 & - \\
\hline & 200 & 23,918 & 29.6 & 7.8 & 1,854 & 57.2 & 26,846 & 30.4 & 6.7 & 1,804 & 30.6 \\
\hline & 400 & 28,389 & 30.4 & 7.8 & 2,224 & 43.3 & 28,529 & 30.3 & 7.7 & 2,184 & 30.5 \\
\hline & 600 & 29,470 & 28.4 & 9.4 & 2,756 & 43.1 & 32,140 & 29.1 & 8.1 & 2,599 & 31.3 \\
\hline & 800 & 28,724 & 27.4 & 10.2 & 2,924 & 35.7 & $33, \mathbf{3 0 8}$ & 28.2 & 9.6 & 3,198 & 35.5 \\
\hline
\end{tabular}

days of November through March (51.55 inches during the second year) had a depressing effect on dry matter yields.

Dry matter content of the forage decreased significantly as the rate of nitrogen increased.

The data shown in table 1 show that the protein yield and percent-protein content of the forage increased with nitrogen rate at all harvest intervals and cutting heights.

The percent nitrogen recovered in the forage was of the same magnitude 
as that obtained with other grass species (12), although in some instances it was very low due mainly to the high amounts of residual nitrogen (204 pounds per acre) in the soil. A drastic drop in the percent recovery of the nitrogen applied with rates above 400 pounds, as occurs with other species (12), did not take place.

Without considering either harvest interval or cutting height, the percent recovery of nitrogen applied was:

\section{Posinds N/acre}

200

400

600

800

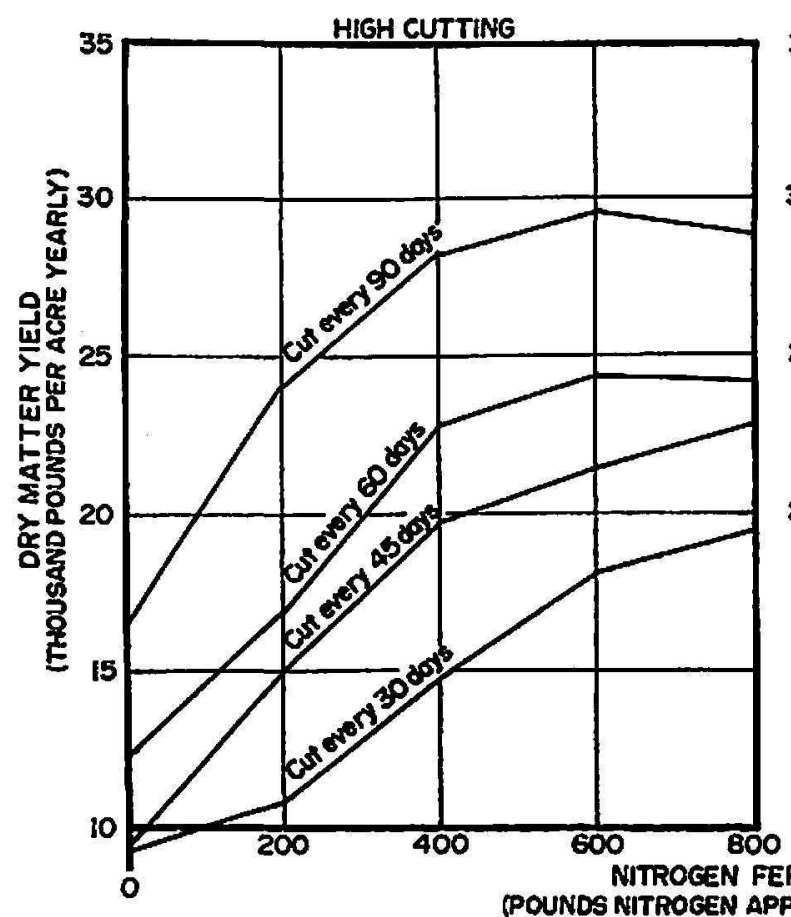

\section{Percenl recovery}

34

42

43

40

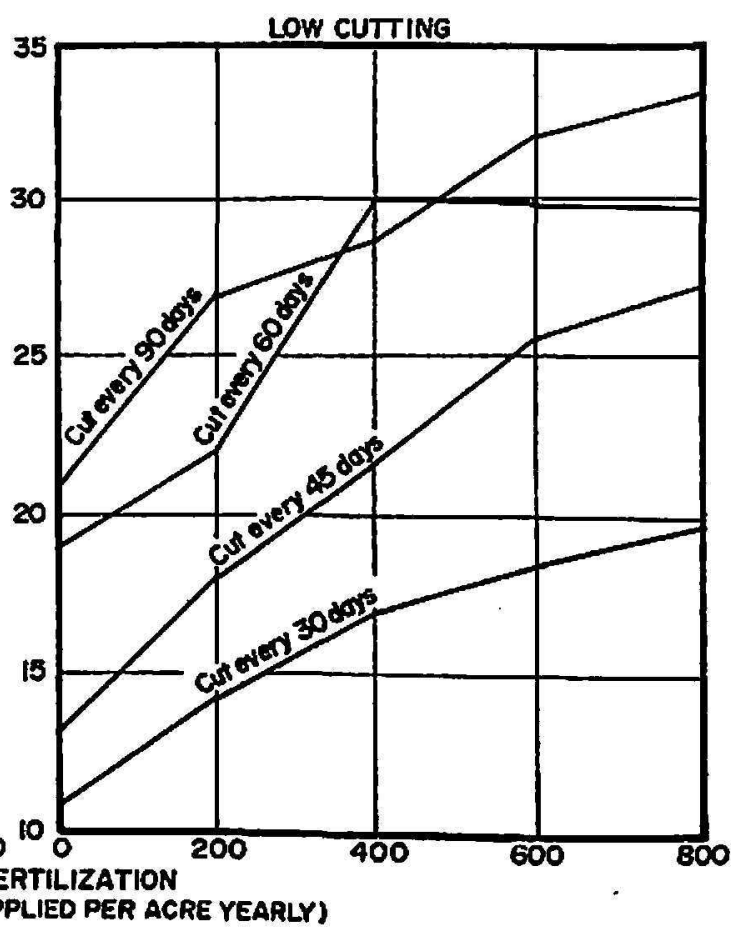

FIG. 1.-Response curves of Star grass to five nitrogen rates, four harvest intervals and two cutting heights (average values for 2 years).

Nitrogen rates did not have a pronounced effect on the percent nitrogen recovered in the forage, except at the 200-pound level. A lower percent recovery normally would be expected as the rates of nitrogen fertilization increased. The low value for the 200-pound rate seems related to the high residual nitrogen content in the soil.

Table 2 shows that forage composition was modified to some extent by the rate of nitrogen fertilization. There was a tendency for the content of phosphorus and calcium to decrease as the rates of nitrogen fertilization increased. However, the lowest contents recorded at the 800-pound rate 


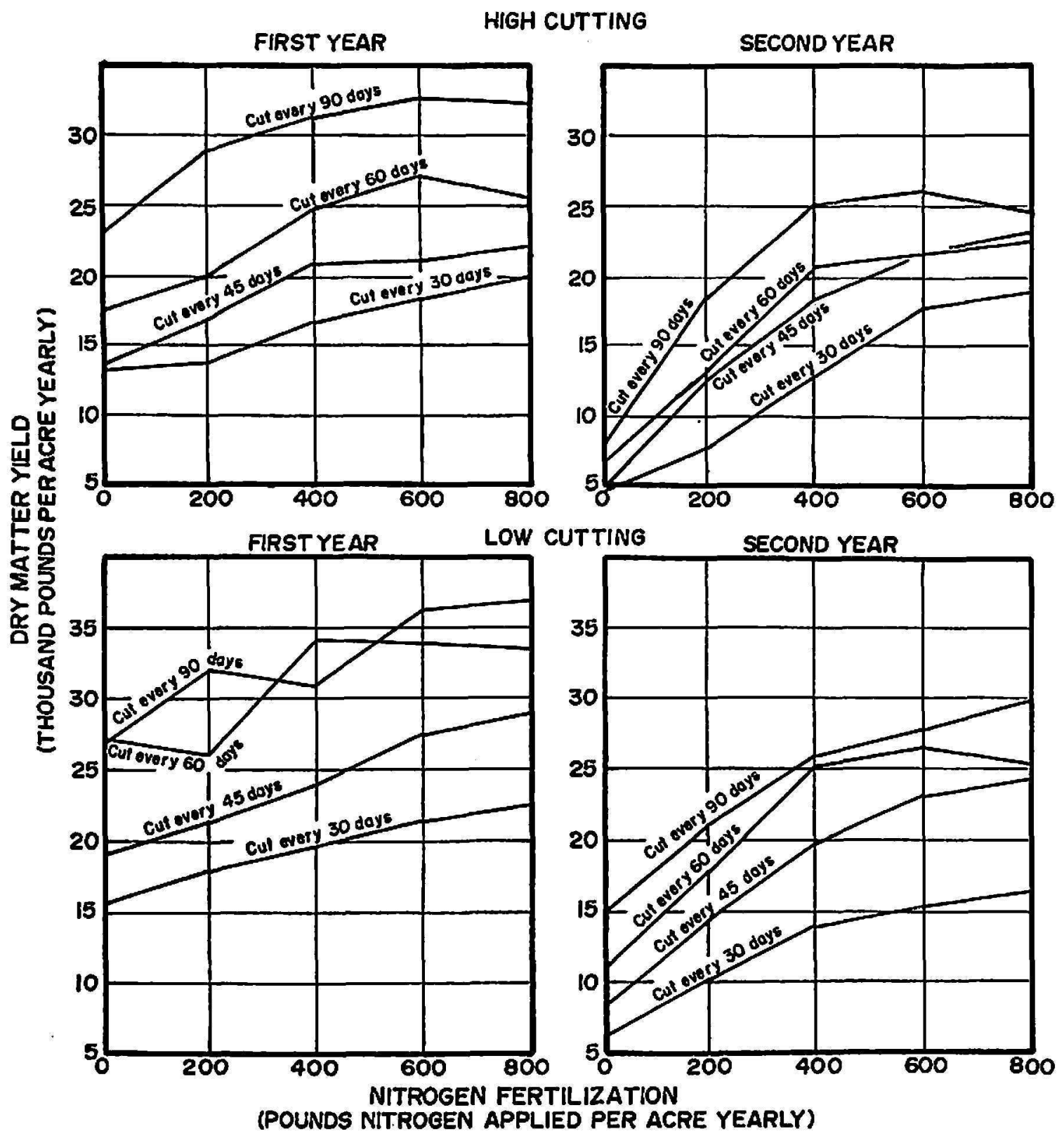

FIa. 2.-Response curves of Star grass to five nitrogen rates, two cutting heights and four harvest intervals during 2 consecutive years.

still satisfy minimum requirements of different types of cattle for these nutrients $(1,6)$.

The potassium and magnesium content of the forage did not follow a definite trend in relation to nitrogen fertilization. Magnesium contents are adequate to prevent occurrence of grass tetany, usually associated with less than 0.2 percent $\mathrm{Mg}$ in forages.

Nutrient withdrawal by Star grass was influenced greatly by the rate of nitrogen fertilization, as shown in table 3 . Without considering the harvest interval or cutting height, the amount of nitrogen removed in the forage increased progressively from 104 at 0-nitrogen fertilization up to 498 pounds 
然. 总

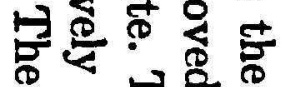

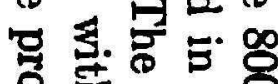

告客客

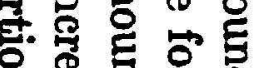
兽. 覃 品电它

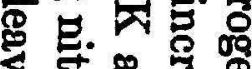
可诺?

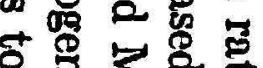

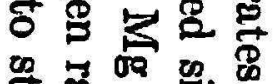

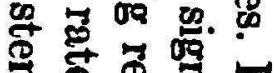

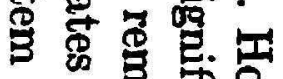
施

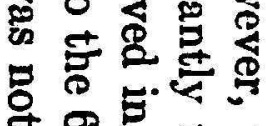
象实 둥

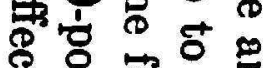

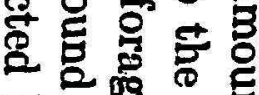
여용. 告数

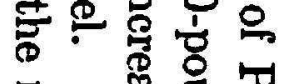

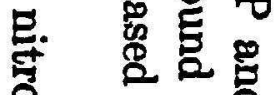
号 总 Е

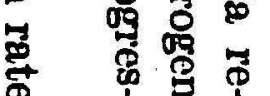

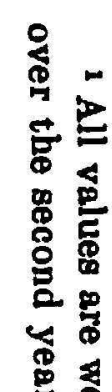

00000

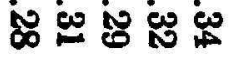

00000 in in $^{\circ}$ in 00000 in 00000 iิ

$$
\text { 兽 }
$$
00000

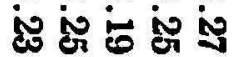
论柁它

N N N N N

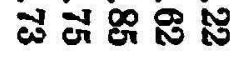

00000

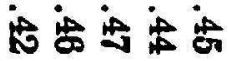

00000 نَّ

TRNN

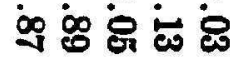
00000

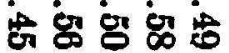

00000

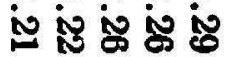

NNーT-

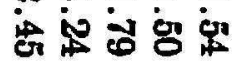

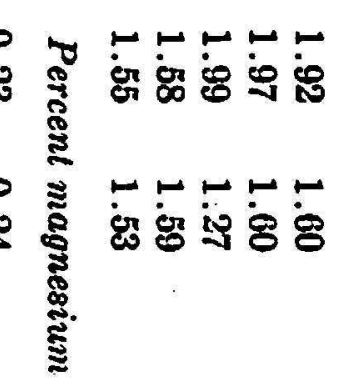

NonN No \&然骂

DODOO NNNNT

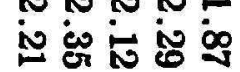

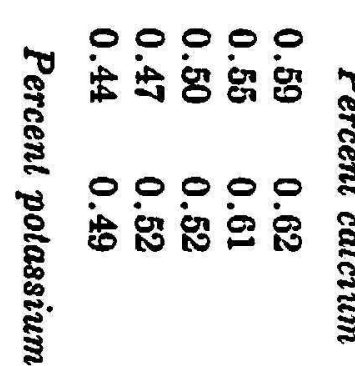

00000 영요영

00000 NTHL

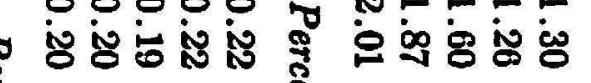
\$

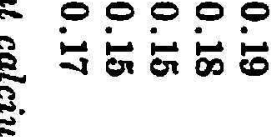
范 ロロロロ ミ

is 00000

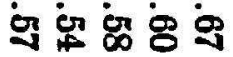

00000 iิ نิن

งNNT

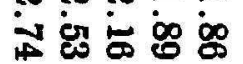
00000 is is is is is

NNT: 옹혀영

0.000

00000

NーRール

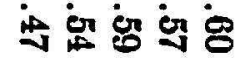
읭

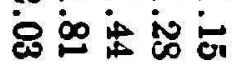

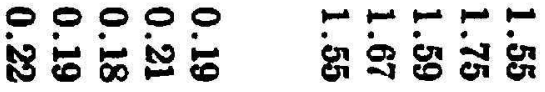

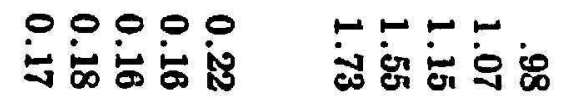


TABLs 3.-Effect of nilrogen rates, harvest inlerval and culting height on mutrient withdrawal by Slar grass 1

\begin{tabular}{|c|c|c|c|c|c|c|c|c|c|c|c|}
\hline \multirow{3}{*}{$\underset{\text { rates }}{\text { Nitrogen }}$} & \multicolumn{5}{|c|}{ Low cut ( 2 inches from the ground) } & \multicolumn{5}{|c|}{ High cut ( 6 inches from the ground) } & \multirow{3}{*}{$\begin{array}{l}\text { General } \\
\text { average }\end{array}$} \\
\hline & \multicolumn{5}{|c|}{ Harvest interval (days) } & \multicolumn{5}{|c|}{ Harvest interval (days) } & \\
\hline & 30 & 45 & 60 & 90 & Average & 30 & 45 & 69 & 90 & Average & \\
\hline & \multicolumn{5}{|c|}{ Pounds/acre/year } & \multicolumn{5}{|c|}{ Pounds/acre/year } & \\
\hline \multicolumn{12}{|c|}{ Nitrogen } \\
\hline 0 & 108 & 118 & 144 & 146 & 129 & 89 & 67 & $\mathbf{7 7}$ & 78 & 78 & 104 \\
\hline 200 & 209 & 216 & 230 & 221 & 219 & 150 & 196 & 174 & 199 & 180 & 199 \\
\hline 400 & 326 & 355 & 305 & 309 & 324 & 280 & 320 & 298 & 290 & 297 & 311 \\
\hline 600 & 425 & 526 & 455 & 385 & 448 & 448 & 456 & 390 & 404 & 425 & 437 \\
\hline 800 & 468 & 597 & 512 & 495 & 518 & 513 & 515 & 458 & 424 & 478 & 498 \\
\hline Average & 307 & 363 & 329 & 311 & 328 & 296 & 311 & 280 & 279 & 292 & 310 \\
\hline
\end{tabular}

\section{Phosphorus}

\begin{tabular}{c|c|c|c|c|c|c|c|c|c|c|c}
0 & 21 & 22 & 24 & 28 & 24 & 15 & 14 & 17 & 17 & 16 & 20 \\
200 & 32 & 37 & 36 & 40 & 36 & 27 & 36 & 26 & 30 & 30 & 33 \\
400 & 44 & 52 & 49 & 40 & 46 & 38 & 46 & 30 & 40 & 41 & 44 \\
600 & 40 & 51 & 49 & 42 & 46 & 51 & 53 & 43 & 46 & 48 & 47 \\
800 & 40 & 52 & 52 & 51 & 49 & 50 & 51 & 44 & 41 & 47 & 48 \\
& - & - & - & - & - & - & - & - & - & - & - \\
Average & 35 & 43 & 42 & 40 & 40 & 36 & 40 & 34 & 35 & 36 & 38
\end{tabular}

Polassium

\begin{tabular}{c|c|c|c|c|c|c|c|c|c|c|c}
0 & 139 & 156 & 212 & 237 & 186 & 105 & 89 & 120 & 123 & 109 & 148 \\
200 & 271 & 307 & 323 & 347 & 312 & 205 & 298 & 268 & 327 & 275 & 294 \\
400 & 405 & 406 & 502 & 333 & 412 & 364 & 391 & 406 & 402 & 391 & 402 \\
600 & 418 & 445 & 386 & 443 & 423 & 506 & 511 & 445 & 436 & 475 & 449 \\
800 & $\mathbf{4 4 4}$ & 456 & 394 & 458 & 438 & 494 & 512 & 423 & 380 & 452 & 445 \\
& - & - & - & - & - & - & - & - & - & - & - \\
Average & 335 & 354 & 363 & 364 & 354 & 335 & 360 & 332 & 334 & 340 & 347
\end{tabular}

Calcium

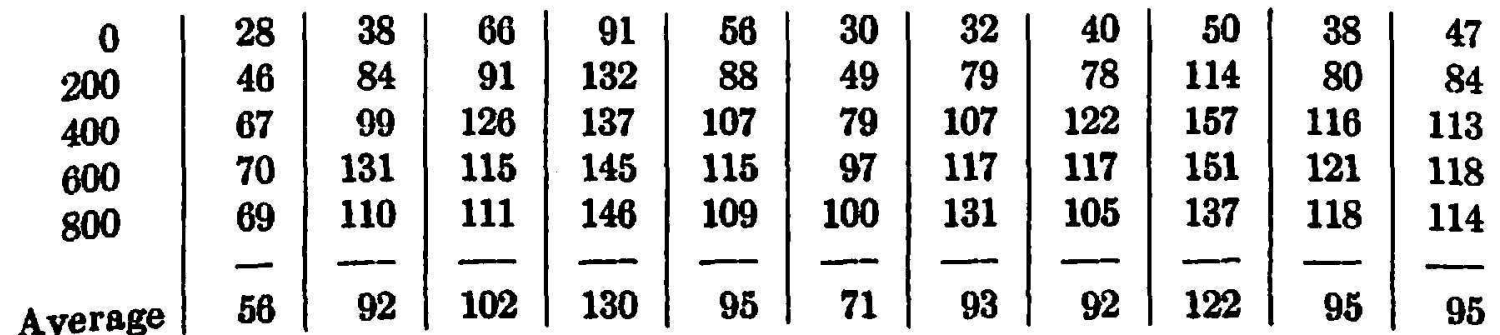

\section{Magnesium}

\begin{tabular}{c|c|c|c|c|c|c|c|c|c|c|c}
0 & 21 & 22 & 25 & 35 & 26 & 13 & 8 & 11 & 15 & 12 & 19 \\
200 & 33 & 30 & 36 & 50 & 37 & 20 & 20 & 32 & 39 & 28 & 33 \\
400 & 41 & 46 & 52 & 70 & 52 & 25 & 34 & 38 & 46 & 36 & 44 \\
600 & 47 & 41 & 60 & 66 & 54 & 44 & 46 & 48 & 50 & 47 & 51 \\
800 & 46 & 58 & 54 & 65 & 56 & 43 & 43 & 53 & 54 & 48 & 52 \\
& - & - & - & - & - & - & - & - & - & - & - \\
Average & 38 & 39 & 45 & 57 & 45 & 29 & 30 & 36 & 41 & 34 & 40 \\
\hline
\end{tabular}

1 All values are weighted averages of 3 replications composited from all harvest over the second year. 
(table 4). At all harvest intervals, the protein content of the leaves and stems increased as the rate of nitrogen fertilization was increased. Leaves were higher in protein content than stems at all nitrogen rates and harvest intervals. The phosphorus content of the leaves and stems was not significantly affected by the nitrogen rates. The leaves had a higher average calcium content than the stems at the 200- and 600-pound nitrogen rates. The stems had a higher potassium content than the leaves. The magnesium content of leaves and stems was fairly constant and was not affected by the rate of nitrogen fertilization.

\section{EFFECT OF THE HARVEST INTERVAL}

A significant increase in dry matter yields occurred at both cutting heights, as the length of the harvest interval increased from 30 to 90 days.

TABLE 4.-Effect of harvest interval and nitrogen rates on composition of leaves and slems of Slar grass when cul al 2 inches from ground

\begin{tabular}{|c|c|c|c|c|c|c|c|c|c|c|c|c|}
\hline \multirow{3}{*}{$\begin{array}{c}\text { Composition, } \\
\text { dry weight } \\
\text { basis }\end{array}$} & \multicolumn{4}{|c|}{ Grass cut every 30 days } & \multicolumn{4}{|c|}{ Grass cut every 45 days } & \multicolumn{4}{|c|}{ Grass cut every 60 days } \\
\hline & \multicolumn{2}{|c|}{200 lbs. N } & \multicolumn{2}{|c|}{600 lbs. $N$} & \multicolumn{2}{|c|}{200 lbs. N } & \multicolumn{2}{|c|}{600 lbs. N } & \multicolumn{2}{|c|}{200 lbs. N } & \multicolumn{2}{|c|}{600 lbs. N } \\
\hline & eaves & Stems & Leaves & Stems & Leaves & Stems & Leaves & Stems & Leaves & Stems & Leaves & Stems \\
\hline & \multicolumn{12}{|c|}{ Percent } \\
\hline & 52.00 & 48.00 & $|53.00|$ & 47.00 & $52.00 \mid$ & $48.00 \mid$ & $52.00 \mid$ & 48.00 & 48.00 & 52.00 & 50.00 & 50.00 \\
\hline Protei & 19.60 & 15.00 & 25.00 & 16.00 & 16.50 & 9.50 & 20.10 & 14.4 & 11.30 & 4.30 & 17.70 & 11.10 \\
\hline $\mathbf{P}$ & .35 & .39 & .30 & .31 & .25 & .25 & .25 & .21 & .22 & .12 & .25 & .18 \\
\hline $\mathbf{K}$ & 2.40 & 4.10 & 2.32 & 4.10 & 2.00 & 3.50 & $|1.92|$ & 2.50 & $\mid 1.92$ & 2.00 & 1.84 & 1.68 \\
\hline $\mathrm{Ca}$ & .61 & .50 & .63 & .40 & .68 & .38 & .59 & .42 & .72 & .28 & .54 & .28 \\
\hline $\mathrm{Mg}$ & .20 & .17 & .18 & .17 & .14 & .19 & .18 & .13 & .16 & .11 & .23 & .22 \\
\hline
\end{tabular}

1 Values are weighted averages for all harvests of three replicates over the second year of experimentation.

At any given nitrogen rate, Star grass produced significantly more dry matter at 90 days than at 30-, 45- or 60-day harvest intervals. The yields obtained at the 30-day harvest interval were significantly lower than those obtained at the other three intervals with both cutting heights.

The length of the harvest interval had a significant effect on the protein content of the forage at all nitrogen levels and cutting heights. The shorter the harvest interval, the higher the protein content of the forage. Protein content dropped sharply from 17 percent at the 30-day harvest interval and with 800 pounds of nitrogen to 10 percent when the grass received the same amount of nitrogen but harvested every 90 days. The length of the harvest interval had no significant effect on the total crude protein yield produced by Star grass. High protein content and low dry matter yield at 
the shorter harvest interval counteracted the high dry matter yield and lower protein content at the longer harvest interval. The length of the harvest interval had no consistent effect on the percent nitrogen recovered in the forage, as shown by the following tabulation:

$\begin{array}{cc}\text { Harvest interval } & \text { Percent nilrogen recosery } \\ 30 \text { days } & 38 \\ 45 \text { days } & 43 \\ 60 \text { days } & 39 \\ 90 \text { days } & 38\end{array}$

The length of the harvest interval has a marked effect on the chemical composition of the forage, as shown in table 2 . The content of $N, P$, and $K$ decreased significantly at both cutting heights and at all nitrogen rates as the length of the harvest interval increased from 30 to 90 days. Calcium content of the forage was not affected significantly by the length of the harvest interval, although there was a tendency to increase as the length of harvest interval increased from 30 to 90 days. The magnesium content of the forage was not affected by the length of the harvest interval.

Intensively managed Star grass withdraws large amounts of nutrients, particularly nitrogen and potassium (table 2). The length of the harvest interval had a marked effect on the withdrawal of some nutrients, but did not affect others. Nitrogen, phosphorus, and potassium withdrawals were not affected by the length of the harvest interval. However, the amounts of calcium and magnesium withdrawn increased significantly as the length of the harvest increased from 30 to 90 days.

The proportion of weight of leaves to stems was not altered by the length of the harvest interval (tablc 4). Protein content, $P$, and $K$ contents of both leaves and stems decreased consistently as the length of the harvest interval increased. Protein content of the leaves was higher than that of the stems at any given harvest interval. There was no difference in the phosphorus content of leaves and stems at the 30- or 45-day harvest intervals, but leaves had more phosphorus than stems at the 90-day harvest interval.

The potassium content of stems was higher than that of leaves at the 30- and 45-day harvest intervals. The calcium content of leaves was not significantly modified by the length of the harvest interval, but there was a measurable decrease in the content of stems as the length of the harvest interval increased from 30 to 60 days. There were no differences in magnesium contents of leaves or stems at any given harvest interval.

Table 5 presents data on the apparent in vitro digestibility, micronutrients and lignin content of Star grass as affected by harvest interval and cutting height. The apparent digestibility of the forage generally decreased and the lignin content increased as the length of the harvest interval in- 
creased. The micronutrient content of the forage generally decreased as the length of the harvest interval increased. There is no explanation for the high $\mathrm{SiO}_{2}$ content of the forage at the short intervals. Normally, a higher $\mathrm{SiO}_{2}$ content would be expected at the longer harvest interval.

Zinc, cobalt and iron are in adequate levels for animal nutrition; molybdenum is low according to published values $(4,5)$. The extremely high levels of copper may be attributed to contamination during grinding of the samples. The manganese content, although high, is not in a range considered to be toxic. The selenium values are normal for most grazing animals.

\section{EFFECT OF CUTTING HEIGHT}

Star grass cut low produced more dry matter and crude protein than when cut high. The difference was more evident as the length of the harvest

TABLe 5.-A pparent digestibilily and micronutrients and lignin content of Slar grass as affecled by cutting height and harvest interval when fertilized with 600 pounds of nitrogen per acre

\begin{tabular}{|c|c|c|c|c|c|c|c|c|c|c|c|}
\hline $\begin{array}{l}\text { Harvest } \\
\text { intervals }\end{array}$ & $\begin{array}{l}\text { Digesti- } \\
\text { bility }\end{array}$ & $\mathrm{SiO}_{2}$ & $\mathbf{Z n}$ & Fe & $\mathbf{M n}$ & $\mathrm{Cu}$ & Mo & Co & $\mathbf{L i}$ & Se & Lignin \\
\hline \multicolumn{12}{|c|}{ Low cul (2 inches from ground) } \\
\hline Doys & Percent & Percent & P.p.m. & P.p.m. & P.p.m. & P.p.m. & P.p.m. & P.p.n. & $P . p . m$. & P.p.m. & Percent \\
\hline 30 & 60 & 1.9 & 44 & - & 417 & 33 & 0.15 & 0.69 & 0.85 & 0.16 & 7.6 \\
\hline 45 & 67 & 1.2 & 46 & 425 & 312 & 30 & 0.07 & 0.13 & 0.60 & 0.15 & 8.4 \\
\hline 60 & 62 & 0.6 & 36 & 94 & 217 & 22 & 0.10 & 0.04 & 0.55 & 0.08 & 10.0 \\
\hline 90 & 46 & 0.8 & 36 & 64 & 242 & 16 & 0.09 & 0.05 & 0.82 & 0.08 & 10.4 \\
\hline \multicolumn{12}{|c|}{ Bigh Cut (6 inches from ground) } \\
\hline 30 & 70 & 0.1 & 35 & 97 & 233 & 24 & 0.04 & 0.08 & 0.37 & 0.08 & 7.9 \\
\hline 45 & 66 & 1.2 & 37 & 103 & 317 & 31 & 0.05 & 0.09 & 0.07 & 0.11 & 8.4 \\
\hline 60 & 59 & 0.6 & 31 & 64 & 267 & 22 & 0.07 & 0.08 & 1.25 & 0.06 & 9.6 \\
\hline 90 & 51 & 0.6 & 36 & 51 & 280 & 19 & 0.07 & 0.05 & 0.32 & 0.07 & 9.6 \\
\hline
\end{tabular}

1 Apparent in vitro digestibility.

interval increased from 30 to 90 days. The percentage dry matter and crude protein content were not significantly affected by cutting height.

The content of nitrogen, phosphorus, calcium, and potassium of the forage was not markedly altcred by varying the cutting height. Nitrogen, calcium, phosphorus and potassium withdrawals were not markedly affected by cutting height.

Cutting height did not consistently affect lignin, silica or micronutrients content of the forage.

\section{INTERACTION BETWEEN VARIABLES}

Nitrogen rates, harvest interval and cutting height had a significant effect on the yield and composition of Star grass. There was no significant 
interaction between nitrogen rates and harvest interval, nor between nitrogen rates and cutting height, as related to yield and composition.

There was a significant interaction, however, between cutting height and harvest interval as related to dry matter yields. The increase in yields due to cutting height was dependent on the length of the harvest interval. As the interval increased from 30 to 90 days, there was a significant increase in dry matter yields due to cutting height.

\section{DISCUSSION}

Star grass, as with other species, responded significantly to increasing nitrogen rates at both cutting heights in terms of dry matter, crude protein yields, and percent protein. The magnitude of the response, however, was dependent on the cutting height. The amount of residual nitrogen in the soil from previous crops (204 pounds per acre) masked the effect of the low nitrogen rates, especially at the short harvest intervals (fig. 2) during the first year of experimentation. The combination of low dry matter yield and high crude protein content at the short harvest intervals counteracted the higher dry matter yields and lower crude protein contents at the longer intervals. This dilution effect accounts for similar crude protein yiclds at the various harvest intervals at both cutting heights. Although the highest dry matter yields were recorded at the 90-day harvest interval, the quality of the forage produced was inferior in quality as indicated by the higher lignin and lower apparent digestibility and crude protein content. On the other hand, the lowest yields were recorded at the 30-day harvest interval, but the forage was of a higher quality as indicated by the high crude protein content, high apparent digestibility and low lignin content. Because the intermediate harvest intervals ( 45 and 60 days) combine a relatively high dry matter yield with an adequate protein and mineral content and a fairly high digestibility, it probably is best to cut Star grass every 45 days during seasons of fast growth and about every 60 days during the season of slow growth.

The high apparent digestibility at the 30-day harvest intcrval when cut high, the high dry matter content at all nitrogen rates and harvest intervals, the higher proportion of leaves, and good quality stems, indicate a great potential of Star grass for pasture purposes.

The ability of Star grass to recover quickly following dry spells has been observed in many places. The aggressiveness of this grass, its resistance to aphids, and its immunity to stunt disease are additional highly desirable attributes.

\section{SUMMARY}

The effect of nitrogen rates, length of harvest intervals, and cutting heights on the yield and composition of a Puerto Rico cultivar of Star grass were determined during 2 consecutive years. 
Dry matter yields increased with nitrogen rates at the two cutting heights tested. However, the response at the various harvest intervals tested (30, 45,60 and 90 days) was dependent on cutting height.

Low cut Star grass responded sharply up to 400 to 600 pounds of nitrogen depending on harvest interval.

High cut Star grass responded sharply to 400 to 600 pounds of nitrogen depending on harvest interval.

The crude protein yield and content increased up to the highest nitrogen rate tested at all harvest intervals and cutting heights.

The percent nitrogen recovered in the forage was of the same magnitude as that obtained with other grasses. However, the nitrogen rates did not have a pronounced effect on the percent nitrogen recovered in the forage.

The proportion of leaves to stems was not affected by nitrogen rates. Leaves were higher in protein content than the stems at all nitrogen rates and harvest intervals.

Dry matter yields increased but protein content decreased as length of harvest interval increased from $\mathbf{3 0}$ to $\mathbf{9 0}$ days.

Length of harvest interval did not affect the percent nitrogen recovered in the forage, but had a marked effect on chemical composition of the forage. The content of $\mathrm{N}, \mathrm{P}$ and $\mathrm{K}$ decreased at both cutting heights and at all nitrogen rates as the length of the harvest interval increased from 30 to 90 days. The apparent digestibility of the forage decreased and lignin content increased as length of harvest interval increased.

Star grass produced higher yields when cut low than high. The difference was more evident as the length of the harvest interval increased from 30 to 90 days.

\section{RESUMEN}

Se estudiaron los efectos de diversos niveles de nitrógeno, intervalo entre cortes y altura al cortarse, en el rendimiento y composición química de la yerba Estrella (Cynodon daclylon) selección Puerto Rico.

La producción de materia seca aumentó según se incrementaron las aplicaciones de nitrógeno. La respuesta a los distintos intervalos de corte se afectó por la altura del corte. Cuando la yerba se cortó a ras del suelo, se registró una respuesta a la aplicación de 400 a 600 libras de nitrógeno dependiendo del intervalo entre cortes.

Cuando se cortó a 6 pulgadas del suelo, la yerba Estrella respondió a la aplicación de 400 a 600 libras de nitrógeno por cuerda dependiendo del intervalo entre cortes.

La producción y contenido de proteína aumentó consistentemente con las aplicaciones de nitrógeno a todos los intervalos y alturas de corte estudiados hasta alcanzar la aplicación más alta.

El porcentaje del nitrógeno aplicado que se recobró en el forraje, fue similar al obtenido en otras yerbas pero el aumento en las aplicaciones de nitrógeno no disminuyó notablemente la utilización del nitrógeno por la planta, como ocurre normalmente con otras yerbas.

La proporción de las hojas a los tallos no sufrió alteración al variarse los nivales 
de nitrógeno. Las hojas siempre tuvieron un contenido mayor de proteína que los tallos a todos los niveles de abonamiento y a todos los intervalos de corte.

La producción aumentó progresivamente a medida que se prolongó el intervalo entre los cortes.

El largo del intervalo entre los cortes no afectó consistentemente la recuperación del nitrógeno aplicado, pero sí alteró notablemente la composición química del forraje.

El contenido de nitrógeno, fósforo y potasio disminuyó a todos los niveles de abonamiento al alargarse el intervalo entre los cortes de 30 a 90 días.

La digestibilidad aparente del forraje seco disminuyó, $y$ el contenido de lignina aumentó según se prolongaba el intervado entre los cortes.

La yerba Estrella tuvo mayor producción cuando se cortó a ras del suelo que cuando se hizo a 6 pulgadas. Esta diferencia fue más notable a medida que el intervalo entre los cortes aumentó de 30 a 90 días.

\section{LITERATURE CITED}

1. Burroughs, W., Nutrient requirements of domestic animals. No. IV. Nutrient requirements of beef cattle, National Academy of Sciences, Natl. Res. Counc., Washington, D.C., 1963.

2. Caro-Costas, R., and Vicente-Chandler, J., Effects of two cutting heights on yields of five tropical grasses, J. Agr. Univ. P.R. 45(1): 46-9, 1961.

3. Caro-Costas, R., Vicente-Chandler, J., and Figarella, J., The yield and composition of five grasses growing in the Humid Mountains of Puerto Rico as affected by nitrogen fertilization, season and harvest procedure, J. Agr. Univ. P.R. 44 (3) : 107-20, 1960.

4. Kubota, J., Trace element studies link animal ailments with soils, Soil Cons. 35 (4) : 86-8, 1969 .

5. - Distribution of cobalt deficiency in grazing animals in relation to soils and forage plants of the United States, Soil Sci. 106: 122-30, 1968.

6. Loosli, J. D., Nutrient requirements of domestic animals. No. III. Nutrient requirements of dairy cattle, Pub. 464, National Academy of Sciences-Natl. Res. Counc., Washington, D.C., 1958.

7. Van Soest, P. J., Wine, R. H., and Moore, L. A., Estimation of the true digestibility of forages by the in vitro digestion of cells walls, Proc. 10th Intern. Grassland Congr., Helsinki, Finland: 438, 1966.

8. Vicente-Chandler, J., Silva, S., and Figarella, J., The effect of nitrogen fertilization and frequency of cutting on the yield and composition of three tropical grasses, Agron. J. 51 : 202-6, 1959.

9. - The effect of nitrogen fertilization and frequency of cutting on yield of $I$. Napier grass, II, Guinea grass, III. Para grass, J. Agr. Univ. P.R. 43(4): 215-48, 1959.

10. Vicente-Chandler, J., Figarella, J., and Silva, S., Effects of nitrogen fertilization and frequency of cutting on yield and composition of Pangola grass in Puerto Rico, J. Agr. Univ. P.R. 45(1): 37-45, 1861.

11. Vicente-Chandler, J., and Figarella, J., The effect of five nitrogen sources on yields and composition of Napier grass, J. Agr. Univ. P.R. 46(2): 102-5, 1962.

12. Vicente-Chandler, J., Caro-Costas, R., Pearson, R. W., Abruña, F., Figarella, J., and Silva, S., Intensive Management of Tropical Forages in Puerto Rico, Agr. Exp. Sta., Univ. P.R., Bull. 187, 152 pp., 1964. 